\title{
Iraq's Future in the Light of the Recent Political and Security Developments
}

Interview with Hisham al-Hashmi, Baghdad based security and political researcher and analyst ${ }^{*}$

Keywords: Iraq, Politics, Security Development.

https://doi.org/10.31271/jopss.10006

- CFS: Most of the major political forces in Iraq condemn sectarianism as the cause for Iraq's main issues including violence and corruption and they claim that they will rise above sectarian and identity politics in dealing with the challenges that face Iraq and the Iraqi citizens. How realistic these claims can be?

- Hashmi: The claim that sectarianism has been the source of all problems in Iraq, including the weakness of the state, is not true. Sectarian identity has been used by the weak and oppressed as a wall for self-protection when the state collapsed and when the state institutions lost their ethno-sectarian neutrality and failed in brining about social justices and enforce national reconciliation. When the state lost its neutrality and its laws were imposed discriminately on some while others were given immunity, people resorted to their sectarian, ethnic, and tribal identity for self-protection.

\footnotetext{
* This interview with Hisham al-Hashmi was conducted in Baghdad on March 14, 2018, by Dr.Zmkan Ali Saleem. Dr Saleem is a researcher and the director of International Affairs Department at the Centre for Future Studies.

zmkan.saleem@centerfs.org

zmkan.saleem@univsul.edu.iq
} 
- CFS: Do you feel that the Shia political factions, the main powerbrokers of Iraq since 2005, are committed to addressing Iraq's lack of domestic cohesion using new approaches?

- Hashmi: Until 25 $5^{\text {th }}$ of October 2017, two political forces from Iraq's major social components, namely the Shias and the Kurds, considered themselves the winners in Iraq given their military victory over IS. The Sunnis and the IS were looked at as the defeated parties within Iraq. Immediately after the defeat of IS, the war of winners started between the Kurds and the Shia, a much expected war over resources and authority. The war took place and as a result the Kurds were defeated in their war with the Shia, who since then, believe that they are heading towards consolidating their power over the entire Iraqi territory. The Shia political factions, including the traditional Right - represented by Nuri al-Maliki, the moderate Right- represented by Haidar al-Abadi, and the hardliners in the left - the leaders of the Popular Mobilization Forces (PMF)- all believe that that have an opportunity towards building a majoritarian government dominated by the Shia factions with a marginal role for the Sunnis and the Kurds. The prime minister's post will be controlled by the Shias and the those who compete over that pivotal post are five Shia-dominated electoral alliances that include: the state of law, the victory alliance, the wisdom trend, the Saeroon, and the Fatah. These have been in control over Iraq's governing institutions, the Iraqi representative council, and they share a strategic depth with Iran, they have an understanding with the West and the are developing a strategic understanding with the Arab world. And thus the Shias have been doing very well in asserting their dominance over Iraq and will continue to do so in the future.

Since 26 of October 2017, when the government forces moved towards the disputed territories, Iraq has been ruled exclusively by the Shia. The Kurds and the Sunnis have become silent oppositions and await an opportunity to 
change the status quo through the elections. There are suggestions from regional powers for the Sunni Arabs and Kurds to get into a sectarian alliance in order to check the Shia dominance in Iraq. This is a valid suggestion and without counterbalancing Shia dominance, Iraq will go down the road of war again. This balance could become the building block for an Iraqi national identity to emerge and unify the country.

An Iraqi national identity is different from an Iraqi identity based on panArab nationalism or religion. The Iraqi identity that the Shia wants to promote is a religious identity based on religious and sectarian nationalism. Shias think they have saved and unified Iraq and therefore the country should belong to them.

\section{- CFS: Will Iraq become a battleground for Iran and the United States in the future?}

- Hashmi: There is a difference between the US-Iran competition in Iraq and the competition and conflict between the two countries in Syria, Lebanon, and Yemen. Unlike in Syria and Lebanon, in Iraq the US has not been Iran's enemy. The US has begun treating and accepting Iran's moderate as well as radical allies as realities except for those who have fought in Syria alongside the Assad regime and the Lebanese Hizbollah. For instance, Qasim Al-Araji, a member of the Badr Organization- classified as a strategic partner of Iran- meets and coordinates with the Americans and the British governments.

The US will remain in Iraq and will work in order to realise the interests of its allies in the Arab Gulf States including reaching an understanding with Iran in Iraq. In order to address the Saudi concerns in Iraq, the US will work in order to contain the PMF, disarm them, and force them to submit to Iraq's formal authorities. 
CFS: Is there any real intention by the Iraqi political factions to carry out reform in the state's institutions and will efforts directed towards rebuilding the government institutions on non-sectarian bases and quotas succeed?

- Hashmi: State institutions in Iraq after 2003 are controlled by a deep government, which is different from the elected government voted by the parliament. The levers of the state, particularly the economic and security institutions, are controlled by the economic committees of the Shia parties. In the security and intelligence institutions, the Shia parties control the most sensitive and powerful positions. They also control the institutions of lawthe courts and judiciary- and therefore justify their actions against their rivals and enemies in the name of, and within the framework, of the law that they control. This deep government can only be purged or removed through an anti-corruption agency. No Prime Minister has attempted to derail the state institutions from the deep government and the party members that control the state's economic and security institutions. On the contrary, all Prime Ministers have allowed for the consolidation of the deep government. The UN and other institutions of the international community have assisted Iraqis by providing training and vision for consolidating the state institutions and enhancing them in terms effectiveness, efficiency, and transparency. But efforts by Iraqis who have been trained to reform the state institutions have been hindered by the deep government.

CFS: To what extent the United States and its allies in the region can manipulate the rivalries and divisions among the Shia factions in order to weaken Iran's influence in Iraq?

- Hashmi: The Shia Islamists constitute a political organization which is not monolithic and various Shia groups and factions compete among themselves for power and authority. However, they are controlled by both Iran and the 
Shia religious establishment (Hawzza) in Iraq led by Grand Ayatolla AliSistani. Iran and the Shia establishment will not allow for the internal rivalry to strengthen to a degree that could result in a complete disintegration of the Shia House in Iraq. Therefore, regardless of the internal divisions among the Shia political entity, they will be forced to develop a unified position in Iraq. This was true during the previous elections in Iraq in 2005, 2010, and 2014 when the Shia parties were led by Iran and the Shia establishment to develop a unified position. Muqtada al-Sadir is a case in point. His Iraqi nationalist stance did not stop him to turn back and join the Shia unified stance. He, at the end, submits to Iran and the Shia establishment that originally control him. Shias are divided but they are controlled. All efforts by the United States to create change in Iraq have to be coordinated with Iran. US's strategy in Iraq is based on reaching political understanding with the Islamic Republic of Iran. Shias differ on many things but they agree on one basic principle: that they have to rule Iraq. The Shia religious establishment in both Iran and Iraq agree that the Prime Minister's position has to be occupied by a Shia figure. Iran is strong and has strong ties with the politically influential Shia groups in Iraq and with Shia factions that have armed militias. Iran has also strong ties with the deep government in Iraq. 